\title{
PENGARUH PARENTING YANG BAIK DAN STORYTELLING TERHADAP KEMAMPUAN BERKOMUNIKASI BAHASA INGGRIS
}

\author{
Muya Burhan \\ Program Studi Pendidikan Bahasa Inggris, \\ Fakultas Bahasa dan Seni, Universitas Indraprasta PGRI \\ mulyaburhan@gmail.com
}

\begin{abstract}
Abstrak
Penelitian ini bertujuan untuk menganalisis dan menguji kebenaran hipotesis mengenai pengaruh parenting dan storytelling terhadap kemampuan berkomunikasi siswa. Hipotesis yang diuji meliputi: 1) terdapat pengaruh yang signifikan parenting dan storytelling terhadap berkomunikasi bahasa Inggris, 2) terdapat pengaruh yang signifikan parenting terhadap berkomunikasi bahasa Inggris, 3) terdapat pengaruh yang signifikan storytelling terhadap kemampuan berkomunikasi bahasa Inggris. Penelitian dilakukan dengan metode eksperimen. Populasi adalah siswa SMP Swasta Depok. Jumlah sampel sebanyak 50 siswa, 25 siswa kelas eksperimen dan 25 siswa kelas kontrol yang dipilih dengan simple random sampling. Instrumen penelitian yaitu tes lisan berkomunikasi berbentuk interview dan kuesioner. Analisis data menggunakan Analysis of Varians (ANOVA) dua arah. Hasil pengujian hipotesis diperoleh kesimpulan sebagai berikut: 1) terdapat pengaruh yang signifikan parenting dan storytelling terhadap kemampuan berkomunikasi bahasa Inggris siswa. Hal ini dibuktikan dengan nilai Sig. $=0,000<0,05$ dan $F_{h}=9,466,2$ ) terdapat pengaruh yang signifikan parenting terhadap kemampuan berkomunikasi bahasa Inggris siswa dengan nilai Sig. $=0,018<0,05$ dan nilai $\left.\mathrm{T}_{\mathrm{h}}=2,454,3\right)$ terdapat pengaruh yang signifikan storytelling terhadap kemampuan berkomunikasi bahasa Inggris siswa dengan nilai Sig. $=0,014<0,05$ dan nilai $\mathrm{t}_{\mathrm{h}}=2,564$.
\end{abstract}

Kata Kunci: parenting, storytelling, berkomunikasi bahasa Inggris.

\begin{abstract}
The research aims to analyze and to test the hypothesis reliability regarding to the effect of parenting and storytelling on students' communication skill. The hypotheses are: 1) there is a significant effect of parenting and storytelling in communicating English, 2) there is a significant effect of parenting in communicating English, 3) there is a significant effect of storytelling in communicating English. The research employs experimental method. The population is students of Private Middle School in Depok. The samples are 50 students, 25 students in the experimental class and 25 students in the control class chosen by simple random sampling. The research instruments are oral communication tests in the form of interviews and questionnaires. Data analysis uses two-way Analysis of Varians (ANOVA). The hypothesis tests result as follows: 1) there is a significant effect of parenting and storytelling on students' English communication skills with the value of Sig. $=0,000<0,05$ and $\left.F_{h}=9,466,2\right)$ there is a significant effect of parenting on students' English communication skills with the value of Sig. $=0.018<0.05$ and $T_{h}$ value $=$ $2.454,3)$ there is a significant effect of storytelling on students' English communication skills with the value of Sig. $=0.014<0.05$ and the value of $t_{h}=2.564$.
\end{abstract}

Keywords: parenting, storytelling, communicating in English 


\section{PENDAHULUAN}

Pada zaman modern sekarang ini masalah kemampuan berbicara bahasa Inggris pada siswa di tingkat SMP merupakan suatu hal yang sangat penting. Bahasa memiliki peranan penting dalam kehidupan manusia. Sebagai makhluk sosial, manusia memerlukan bahasa untuk berkomunikasi dan berinteraksi dengan sesamanya. Dalam pengembangan bahasa, para pendidik dapat menggunakan beragam metode dalam menyampaikan pesan pembelajaran yang dapat merangsang dan menambah kosakata anak serta dapat menumbuhkan kemampuan berbicara pada anak, salah satu metodenya adalah dengan storytelling atau bercerita.

Para pendidik dituntut untuk memiliki kompetensi dalam bercerita, karena menjalankan program storytelling ini berkaitan erat dengan kemampuan berbicara di mana di dalamnya terdapat satu komunikasi, yaitu penyampaian pesan yang dilakukan komunikator, dalam hal ini para pendidik kepada anak. Hal ini diperkuat oleh Bailey dan Nunan (2005), bahwa berbicara merupakan proses interaksi dalam membangun makna yang melibatkan antara proses produksi ujaran dan proses penyampaian ujaran.

Siswa dikatakan mampu dalam berbicara bahasa Inggris apabila memiliki kemampuan perspektif motorik dan kemapuan interaktif. Kemampuan berpikir seseorang dalam mengekspresikan gagasan akan nampak di saat ia berbicara. Menurut Tarigan (2008), keterampilan berbahasa memiliki keterkaitan yang sangat memengaruhi satu sama lain, di mana keterampilan menyimak merupakan keterampilan pertama yang diperoleh manusia dan diikuti dengan keterampilan lainnya, yaitu keterampilan berbicara, lalu membaca dan menulis.
Namun, pada kenyataannya tidak semua siswa memiliki kemampuan yang baik dalam berbicara.

$$
\text { Pada saat berbicara terkadang }
$$
seorang siswa belum memiliki kemampuan untuk menyesuaikan dengan tepat apa yang ada dalam pikirannya dengan apa yang diucapkannya sehingga orang yang mendengar kurang memahami apa yang dibicarakannya. Kemampuan untuk menyesuaikan apa yang ada dalam pikiran itulah yang menjadikan siswa bila diberi tugas oleh guru untuk berbicara di depan kelas mengalami hambatan. Hambatan itu dapat terjadi karena kurangnya pendekatan orang tua atau guru dengan memberikan perhatian dan kebebasan kepada siswa ketika berbicara menyampaikan pendapat sehingga mereka merasa kesulitan ketika berbicara mengekspresikan gagasannya.

Parenting dan storytelling memegang peranan yang sangat penting dalam memberikan pencerahan berpikir, semangat dan rasa senang dalam berbicara bahasa Inggris sehingga siswa ketika mendapatkan parenting yang baik akan memiliki semangat yang besar untuk meniru kemampuan orang tua mereka dalam berbicara. Tidak sedikit guru bahasa Inggris merasa kesulitan dalam mengajarkan keterampilan ini. Hampir seluruh aspek bahasa, seperti ejaan, pelafalan, kelancaran, intonasi, kosakata, tata bahasa, dan lain-lain dipelajari siswa untuk dapat menguasai keterampilan ini. Selain itu, bukan hanya kompleksitas keterampilan itu saja yang harus dihadapi oleh guru, tetapi guru juga harus berupaya keras dalam memotivasi siswa untuk berbicara menggunakan bahasa Inggris. Graddol (2006) mengungkapkan bahwa bahasa Inggris merupakan media yang diperlukan pada era globalisasi sehingga siswa yang memiliki keterampilan 
bahasa Inggris yang baik akan dengan mudah berkompetisi secara global.

Penelitian ini mengarah pada tiga variabel, yaitu parenting, storytelling atas berkomunikasi bahasa Inggris siswa kelas VII Sekolah Menengah Pertama di Depok. Menurut Arikunto (2006:97), "Variabel merupakan gejala yang bervariasi misalnya jenis kelamin, umur, berat badan, tinggi badan, dan lain-lain, dan jenisnya dapat dibedakan menjadi dua macam, yaitu variabel kuantitatif seperti luas, umur, berat badan, dan variabel kualitatif seperti kemakmuran, kepandaian, maka tiga variabel di atas sebagai target penelitian merupakan variabel kuantitatif yang tidak dapat dihitung dengan angka secara pasti."

Variabel yang ingin diketahui korelasinya adalah seperti yang dirumuskan dalam uraian tujuan penelitian untuk mengetahui:

1. Untuk mengetahui pengaruh antara parenting $\left(\mathrm{X}_{1}\right)$ dan storytelling $\left(\mathrm{X}_{2}\right)$ dengan kemampuan berkomunikasi bahasa Inggris siswa (Y).

2. Untuk mengetahui pengaruh antara parenting $\left(\mathrm{X}_{1}\right)$ dengan kemampuan berkomunikasi bahasa Inggris siswa (Y).

3. Untuk mengetahui pengaruh antara variabel storytelling $\left(\mathrm{X}_{2}\right)$ dengan kemampuan berkomunikasi bahasa Inggris siswa (Y).

\section{METODE PENELITIAN}

Penelitian dilaksanakan dalam bentuk penelitian lapangan, sedangkan metode yang digunakan adalah deskriptif analisis. Dalam penelitian ini data dan informasi dikumpulkan dari responden dengan menggunakan tes/interview. Setelah data diperoleh lalu hasilnya dipaparkan secara deskriptif pada akhir penelitian. "Penelitian dilakukan untuk suatu tindakan yang sifatnya deskriptif, yaitu melukiskan hal-hal yang mengandung fakta, fungsinya merumuskan dan melukiskan apa yang terjadi" (Ali dalam Sugiyono, 2008:5). Berkaitan dengan pengertian metode deskriptif menjelaskan bahwa penelitian ditinjau dari hadirnya variabel dan saat terjadinya, maka "Penelitian yang dilakukan dengan menjelaskan atau menggambarkan variabel masa lalu dan sekarang (sedang terjadi) adalah penelitian deskriptif" (Arikunto, 2006:10). Tujuan penelitian deskriptif ini adalah untuk membuat deskripsi, gambaran atau lukisan secara sistematis, faktual dan akurat mengenai fakta-fakta dan hubungan antara fenomena yang diselidiki.

Berdasarkan pengertian para pakar di atas, maka penulis menarik kesimpulan bahwa metode survei deskriptif cocok digunakan dalam penelitian ini karena sesuai dengan maksud dari peneliti, yaitu untuk memperoleh gambaran pengaruh parenting dan storytelling terhadap kemampuan berkomunikasi bahasa Inggris siswa kelas VII SMP swasta Depok. Sebelum melakukan analisis data tentang pengaruh variabel data kemudian teknik analisa data dengan menggunakan statistik inferesial, korelasi sederhana dan korelasi ganda, korelasi parsial serta regresi berganda. Korelasi memerlukan minimal dua variabel, sedangkan korelasi ganda memerlukan tiga variabel pada penelitian ini. Variabel bebas pertama adalah parenting (X1), variabel bebas kedua adalah storytelling (X2) dan variabel terikatnya adalah kemampuan berkomunikasi $(\mathrm{Y})$ yang sesuai dengan gambar 1 sebagai berikut

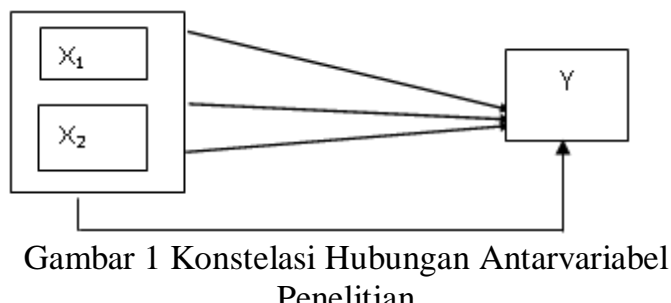

Penelitian 
Keterangan:

$$
\begin{aligned}
\mathrm{X} 1 & =\text { Parenting } \\
\mathrm{X} 2 & =\text { Storytelling } \\
\mathrm{Y} & =\text { Kemempuan Berkomunikasi } \\
& \text { Bahasa Inngris }
\end{aligned}
$$

\section{HASIL DAN PEMBAHASAN}

\section{A. Deskripsi Data}

Data kemampuan berkomunikasi bahasa Inggris diperoleh dari nilai tes 50 siswa yang menjadi sampel penelitian. Nilai yang diperoleh adalah terendah 60 , tertinggi 90 , ratarata sebesar 78,80, median sebesar 80,00, modus sebesar 70 dan simpangan baku sebesar 9,179.

Tabel 1 Deskripsi Data Kemampuan Berkomunikasi Bahasa Inggris

\begin{tabular}{|l|l|l|}
\hline Statistics & & \\
\hline $\begin{array}{l}\text { Kemampuan } \\
\text { Berkomunikasi } \\
\text { Bahasa Inggris }\end{array}$ & & \\
\hline $\mathrm{N}$ & Valid & 50 \\
\hline & Missing & 0 \\
\hline Mean & & 78.80 \\
\hline Median & & 80.00 \\
\hline Mode & & 70 \\
\hline Std. Deviation & & 9.179 \\
\hline Minimum & & 60 \\
\hline Maximum & & 90 \\
\hline
\end{tabular}

Data Parenting $\left(\mathrm{X}_{1}\right)$ terhadap metode pembelajaran diperoleh skor angket yang dijawab 50 siswa yang menjadi sampel penelitian dihasilkan skor terendah 50, skor tertinggi 90, skor rerata sebesar 75,40, median
75,00, modus sebesar 70, dan simpangan baku sebesar 8,855 .

Tabel 2 Deskripsi Data Penelitian Parenting

\begin{tabular}{|l|l|l|}
\hline Statistics & & \\
\hline Parenting & & \\
\hline $\mathrm{N}$ & Valid & 50 \\
\hline & Missing & 0 \\
\hline Mean & & 75.40 \\
\hline Median & & 75.00 \\
\hline Mode & & 70 \\
\hline $\begin{array}{l}\text { Std. } \\
\text { Deviation }\end{array}$ & & 8.855 \\
\hline Minimum & & 50 \\
\hline Maximum & & 90 \\
\hline
\end{tabular}

Data Storytelling $\left(\mathrm{X}_{2}\right)$. Data storytelling diperoleh dari nilai tes yang dijawab 50 siswa sebagai responden dihasilkan nilai terendah 60, nilai tertinggi 90 , nilai rerata sebesar 75,90, median sebesar 75,00, modus sebesar 75 dan simpangan

\begin{tabular}{|c|c|c|}
\hline \multicolumn{3}{|c|}{ Statistics } \\
\hline \multicolumn{3}{|c|}{ Storytelling } \\
\hline \multirow{2}{*}{$\mathrm{N}$} & Valid & 50 \\
\hline & Missing & 0 \\
\hline \multicolumn{2}{|c|}{ Mean } & 75.90 \\
\hline \multicolumn{2}{|c|}{ Median } & 75.00 \\
\hline \multicolumn{2}{|c|}{ Mode } & 75 \\
\hline \multicolumn{2}{|c|}{ Std. Deviation } & 8.311 \\
\hline \multicolumn{2}{|c|}{ Minimum } & 60 \\
\hline \multicolumn{2}{|c|}{ Maximum } & 90 \\
\hline
\end{tabular}
baku sebesar 8,311.

Tabel 3 Deskripsi Data Penelitian StoryTelling

\section{Uji Normalitas Data}

Persyaratan regresi yang baik jika data penelitian mengikuti distribusi normal

Tabel 4 Uji Normalitas Data

One-Sample Kolmogorov-Smirnov Test

\begin{tabular}{|l|l|l|}
\hline Kemampuan & Parenting & Storytelling \\
Berkomunikasi & & \\
\hline
\end{tabular}




\begin{tabular}{|l|l|l|l|l|}
\hline $\mathrm{N}$ & 50 & 50 & 50 \\
\hline \multirow{2}{*}{$\begin{array}{l}\text { Normal } \\
\text { Parameters } \mathrm{a}, \mathrm{b}\end{array}$} & Mean & 78.80 & 75.40 & 75.90 \\
\cline { 2 - 5 } Most & Std. Deviation & 9.179 & 8.855 & 8.311 \\
Extreme & Absolute & .231 & .229 & .123 \\
\cline { 2 - 5 } Differences & Positive & .231 & .229 & .123 \\
\cline { 2 - 5 } & Negative & -.209 & -.198 & -.123 \\
\hline Kolmogorov-Smirnov Z & 1.635 & 1.619 & .871 \\
\hline Asymp. Sig. (2-tailed) & .010 & .011 & .433 \\
\hline \multicolumn{4}{|l|}{ a. Test distribution is Normal. } \\
\hline \multicolumn{4}{|l|}{ b. Calculated from data. } \\
\hline
\end{tabular}

Bila dilihat dari hasil perhitungan di atas, maka dapat dikatakan bahwa keterampilan kemampuan berkomunikasi bahasa Inggris siswa SMP Karya Bangsa Depok tergolong baik. Hal ini diindikasikan dengan perolehan skor rata-rata sebesar 78,80. Persepsi terhadap metode pembelajaran siswa SMP Karya Bangsa Depok dikatakan baik yang diindikasikan dengan perolehan skor rerata sebesar 75,40 di atas skor mediannya. Dari tabel di atas menunjukkan bawha uji hipotesis yang menyatakan distribusi data pada analisis regresi ini mengikuti distribusi normal. Hal ini ditunjukkan dengan semua nilai Asymp. Sig >0,05. Hal ini berarti semua data berdistribusi normal.

\section{Uji Linearitas}

Uji linearitas dilakukan untuk menentukan teknik dalam analisis regresi apakah variabel bebas $\left(\mathrm{X}_{1}\right.$ dan $\left.\mathrm{X}_{2}\right)$ dan variabel terikat $(\mathrm{Y})$ terbentuk linear. Uji linearitas ini menggunakan perhitungan SPSS 20.0

\section{Linearitas Regresi Pengaruh Variabel $\mathrm{X}_{1}$ atas $\mathrm{Y}$}

Hasil uji linearitas antara parenting dengan kemampuan berkomunikasi Bahasa Inggris, perhitungan SPSS 20.00 sebagai berikut:

Tabel 5 Hasil Pengujian Linearitas Regresi Variabel Y atas $\mathrm{X}_{1}$

\begin{tabular}{|c|c|c|c|c|c|c|c|}
\hline \multicolumn{8}{|c|}{ ANOVA Table } \\
\hline & & & $\begin{array}{l}\text { Sum of } \\
\text { Squares }\end{array}$ & df & $\begin{array}{l}\text { Mean } \\
\text { Square }\end{array}$ & $\mathrm{F}$ & Sig. \\
\hline \multirow{5}{*}{$\begin{array}{l}\text { Kemampuan } \\
\text { Berkomunikasi } \\
\text { Bahasa Inggris } \\
\text { Storytelling }\end{array}$} & \multirow{3}{*}{$\begin{array}{l}\text { Between } \\
\text { Groups }\end{array}$} & (Combined) & 1008.754 & 6 & 168.126 & 2.318 & .050 \\
\hline & & Linearity & 808.307 & 1 & 808.307 & $\begin{array}{l}11.14 \\
3\end{array}$ & .002 \\
\hline & & $\begin{array}{l}\text { Deviation } \\
\text { from } \\
\text { Linearity }\end{array}$ & 200.447 & 5 & 40.089 & .553 & .735 \\
\hline & \multicolumn{2}{|c|}{ Within Groups } & 3119.246 & 43 & 72.541 & & \\
\hline & \multicolumn{2}{|c|}{ Total } & 4128.000 & 49 & & & \\
\hline
\end{tabular}

Berdasarkan hasil perhitungan di atas diperoleh hasil perhitungan Deviation from Linear dengan Fo $=0,373$ dan Sig. $=0,773>0,05$. Hal ini memiliki pengertian bahwa variabel parenting dengan kemampuan berkomunikasi bahasa Inggris memiliki hubungan yang linear. 
Linearitas Regresi pengaruh variable $\mathrm{X}_{2}$ atas $\mathrm{Y}$

Hasil uji linearitas regresi antara storytelling dengan keterampilan Kemampuan berkomunikasi Bahasa Inggris, perhitungan SPSS 20.0 sebagai berikut:

Tabel 6. Hasil Pengujian Linearitas Regresi Variabel $\mathrm{Y}$ atas $\mathrm{X}_{2}$

\begin{tabular}{|l|l|l|l|l|l|l|}
\hline \multicolumn{9}{|l|}{ ANOVA $^{\text {a }}$ Model } & $\begin{array}{l}\text { Sum of } \\
\text { Squares }\end{array}$ & df & $\begin{array}{l}\text { Mean } \\
\text { Square }\end{array}$ & F & Sig. \\
\hline \multirow{3}{*}{1} & Regression & 1185.343 & 2 & 592.671 & & 9.466 \\
\cline { 2 - 7 } & Residual & 2942.657 & 47 & 62.610 & & \\
\cline { 2 - 7 } & Total & 4128.000 & 49 & & & \\
\hline a. Dependent Variable: Kemampuan Berkomunikasi Bahasa Inggris \\
\hline
\end{tabular}

Berdasarkan hasil perhitungan di atas diperoleh hasil Deviation from Linearity dengan Fo $=0,553$ dan Sig. $=0,735>0,05$. Hal ini memiliki pengertian bahwa variabel storytelling dengan kemampuan berkomunikasi bahasa Inggris memiliki hubungan yang linear.

\section{B. Pengujian Hipotesis}

Hasil perhitungan dan pengujian dapat dilihat pada tabel di bawah ini:

Tabel 7 Hasil Perhitungan Pengujian Koefisien Korelasi Ganda Variabel $\mathrm{X}_{1}$ dan $\mathrm{X}_{2}$ terhadap Y

\begin{tabular}{|l|l|l|l|l|}
\hline \multicolumn{5}{|c|}{ Model Summary } \\
\hline \multicolumn{1}{|c|}{ Model } & \multicolumn{1}{|c|}{ R Square } & $\begin{array}{c}\text { Adjusted R } \\
\text { Square }\end{array}$ & $\begin{array}{c}\text { Std. Error of } \\
\text { the Estimate }\end{array}$ \\
\hline 1 & $.536^{\mathrm{a}}$ & .287 & .257 & 7.913 \\
\hline \multicolumn{4}{|l|}{ a. Predictors: (Constant), Storytelling, Parenting } \\
\hline
\end{tabular}

Tabel 8 Hasil Perhitungan Pengujian Signifikansi Koefisien Regresi Ganda Variabel $\mathrm{X}_{1}$ dan $\mathrm{X}_{2}$ terhadap Y

\begin{tabular}{|c|c|c|c|c|c|c|}
\hline \multicolumn{7}{|c|}{ Coefficients $^{\mathrm{a}}$} \\
\hline \multirow{2}{*}{\multicolumn{2}{|c|}{ Model }} & \multicolumn{2}{|c|}{$\begin{array}{c}\text { Unstandardized } \\
\text { Coefficients }\end{array}$} & \multirow{2}{*}{$\begin{array}{c}\text { Standardized } \\
\text { Coefficients }\end{array}$} & \multirow[t]{2}{*}{$\mathrm{t}$} & \multirow[t]{2}{*}{ Sig. } \\
\hline & & $\mathrm{B}$ & $\begin{array}{l}\text { Std. } \\
\text { Error }\end{array}$ & & & \\
\hline \multirow{3}{*}{1} & (Constant) & 25.640 & 12.276 & & 2.089 & .042 \\
\hline & Parenting & .332 & .135 & .321 & 2.454 & .018 \\
\hline & Storytelling & .370 & .144 & .335 & 2.564 & .014 \\
\hline
\end{tabular}


Pengaruh parenting dan storytelling secara bersama-sama terhadap kemampuan berkomunikasi bahasa Inggris

Hipotesis yang diuji:

$H_{0}: \beta_{y 1}=\beta_{y 2}=0$

$H_{1}: \beta_{y 1} \neq 0$ atau $\beta_{y 2} \neq 0$

Artinya:

$\mathrm{H}_{0}$ : tidak terdapat pengaruh parenting dan storytelling secara bersama-sama terhadap kemampuan berkomunikasi bahasa Inggris.

$\mathrm{H}_{1}$ : terdapat pengaruh parenting dan storytelling secara bersama-sama terhadap kemampuan berkomunikasi bahasa Inggris.

Dari tabel 6 dapat dinyatakan bahwa terdapat pengaruh yang signifikan parenting dan storytelling secara bersama-sama terhadap kemampuan berkomunikasi bahasa Inggris. Hal ini dibuktikan dengan perolehan nilai Sig. 0,000 $<0,05$ dan Fh $=9,466$.

Sementara itu, persamaan garis regresi ganda dapat dinyatakan dengan $=25,640+0,332 \mathrm{X} 1+0,370 \mathrm{X} 2$. Hal ini memiliki pengertian bahwa kenaikan satu skor variabel parenting dan storytelling memberikan kontribusi sebesar 0,332 oleh X1 dan 0,370 oleh X2 terhadap variabel kemampuan berkomunikasi bahasa Inggris. Dari tabel 7 juga dapat menjelaskan bahwa secara bersama-sama variabel parenting dan storytelling memberikan kontribusi sebesar $28,7 \%$ terhadap variabel kemampuan berkomunikasi bahasa Inggris.

\section{Pengaruh parenting terhadap kemampuan berkomunikasi bahasa Inggris}

Hipotesis yang diuji:

$$
H_{0}: \beta_{y 1}=0
$$$$
H_{1}: \beta_{y 1} \neq 0
$$

Artinya:

$\mathrm{H}_{0}$ : tidak terdapat pengaruh parenting terhadap kemampuan berkomunikasi bahasa Inggris
$\mathrm{H}_{1}$ : terdapat pengaruh parenting terhadap kemampuan berkomunikasi bahasa Inggris

Dari tabel 8 dapat dinyatakan bahwa terdapat pengaruh yang signifikan parenting terhadap kemampuan berkomunikasi bahasa Inggris. Hal ini dibuktikan dengan perolehan nilai Sig. $0,018<0,05$ dan th $=2,454$.

Adapun kontribusi variabel parenting terhadap kemampuan berkomunikasi bahasa Inggris adalah:

$\mathrm{KD}=$ Nilai $\mathrm{x}$ Nilai Korelasi Pasialnya $\left(r_{x 1 y}\right) \times 100 \%$

$\mathrm{KD}=0,321 \times 0,433 \times 100 \%=13,9 \%$

Dari hasil perhitungan di atas dapat dinyatakan bahwa kontribusi parenting dalam meningkatkan kemampuan berkomunikasi bahasa Inggris sebesar $9,33 \%$.

Pengaruh storytelling terhadap Kemampuan berkomunikasi bahasa Inggris

Hipotesis yang diuji:

$H_{0}: \beta_{y 2}=0$

$H_{1}: \beta_{y 2} \neq 0$

Artinya:

$\mathrm{H}_{0}$ : tidak terdapat pengaruh storytelling terhadap kemampuan berkomunikasi bahasa Inggris

$\mathrm{H}_{1}$ : terdapat pengaruh storytelling terhadap kemampuan berkomunikasi bahasa Inggris

Dari table 8 dapat dinyatakan bahwa terdapat pengaruh yang signifikan storytelling terhadap kemampuan berkomunikasi bahasa Inggris. Hal ini dibuktikan dengan perolehan nilai Sig. $0,014<0,05$ dan th $=2,564$.

Adapun kontribusi variabel storytelling terhadap kemampuan berkomunikasi bahasa Inggris adalah:

$\mathrm{KD}=$ Nilai $\mathrm{x}$ Nilai Korelasi Pasialnya $\left(r_{x 2 y}\right) \times 100 \%$

$\mathrm{KD}=0,335 \times 0,443 \times 100 \%=14,84 \%$

Dari hasil perhitungan di atas dapat dinyatakan bahwa kontribusi storytelling dalam meningkatkan 
kemampuan berkomunikasi bahasa Inggris sebesar $14,84 \%$.

\section{Pengaruh parenting dan storytelling secara bersama-sama terhadap kemampuan berkomunikasi bahasa Inggris}

Hasil penelitian di atas menyimpulkan bahwa parenting dan storytelling secara bersama-sama telah memberikan pengaruh positif yang signifikan terhadap peningkatan kemampuan berkomunikasi bahasa Inggris siswa SMP Karya Bangsa Depok. Dalam mempelajari bahasa, bahasa ibu contohnya, seorang anak akan belajar mendengar terlebih dahulu, lalu belajar berbicara, membaca dan terakhir menulis. Proses perkembangan keterampilan berbahasa anak berlangsung secara bertahap dan berkesinambungan. Secara alamiah ataupun tidak, perlahan anak akan belajar memahami dan menghasilkan bunyi bahasa (phonology) terlebih dahulu, yaitu berkaitan dengan keterampilan mendengarkan dan berbicara untuk menyatakan sikap, perasaan, dan sebagainya, lalu belajar membaca dan menulis.

Kemampuan berbicara siswa dianggap penting karena siswa dapat mengekspresikan pikiran dan perasaannya secara cerdas sesuai konteks dan situasi pada saat dia sedang berbicara. Dengan kemampuan berbicara ternyata akan mampu melahirkan generasi masa depan yang kreatif sehingga mampu melahirkan tuturan yang komunikatif, jelas dan mudah dipahami. Keberhasilan kemampuan berbicara siswa ditentukan oleh banyak faktor diantaranya parenting, potensi siswa, kemampuan guru, kurikulum, teknik mengajar, lingkungan masyarakat, sarana prasarana dan sebagainya. Di antara faktorfaktor tersebut, parenting memiliki posisi yang penting dalam rangka mewujudkan kemampuan berkomunikasi siswa dalam berbahasa Inggris.

Parenting dan storytelling memegang peranan yang sangat penting dalam memberikan pencerahan berpikir, semangat dan rasa senang dalam berbicara bahasa Inggris. Sehingga siswa yang mendapatkan parenting yang baik akan memiliki semangat yang besar untuk meniru keterampilan berbicara orang tua mereka, tidak sedikit guru bahasa Inggris merasa kesulitan dalam mengajarkan keterampilan ini. Hampir seluruh aspek bahasa, seperti ejaan, pelafalan, kelancaran, intonasi, kosakata, tata bahasa, dan lain sebagainya, harus dipelajari siswa untuk dapat menguasai keterampilan ini.

Pengaruh parenting terhadap kemampuan berkomunikasi bahasa Inggris. Hasil penelitian di atas menyimpulkan bahwa parenting telah memberikan pengaruh positif yang cukup signifikan terhadap peningkatan kemampuan berkomunikasi bahasa Inggris siswa SMP Karya Bangsa Depok. Parenting adalah proses interaksi berkelanjutan antara orang tua dan anak-anak mereka yang meliputi aktivitas-aktivitas berikut: memberi makan (nourishing), memberi petunjuk (guiding), dan melindungi (protecting) anak-anak ketika mereka bertumbuh. Aktivitasaktivitas parenting biasanya terjadi dalam lingkungan keluarga, tetapi parenting tidak terbatas hanya pada mereka yang melahirkan anak. Tanggung jawab parenting juga dilakukan oleh pihak-pihak lain dalam masyarakat, seperti anggotaanggota jemaat di gereja, para guru di sekolah, pembantu rumah tangga, perawat bayi (baby sitter), dan bahkan teman-teman si anak, serta media masa (TV, surat kabar, dan majalah). Kendati demikian, orang tua adalah pihak yang paling bertanggung jawab dalam mengasihi dan memperhatikan anakanak serta menolong mereka bertumbuh.

Parenting juga merupakan suatu proses membesarkan dan mendukung perkembangan fisik dan mental yang juga meliputi emosional, sosial, spiritual dan intelektual anak dari bayi hingga dewasa. Tentu saja tujuannya untuk menghasilkan generasi muda atau anak-anak yang cerdas, bukan saja cerdas intelektual, tetapi juga cerdas emosional dan spiritualnya. Gaya pengasuhan anak pun memiliki peranan penting, anak yang mendapatkan pengasuhan yang baik, biasanya juga memiliki budi pekerti dan sopan santun yang baik dalam masyarakat.

Dalam proses parenting, gaya orang tua dalam mengasuh anak memilki banyak perbedaan. Gaya dalam pengasuhan anak itu 
akan terlihat dalam kehidupan sehari-hari anak, sikap dan perilaku anak merupakan hasil dari sistem pengasuhan yang diterapkan orang tua. Kelas sosial, tingkat kesejahteraan, budaya orang tua dan lingkungan sekitar memiliki pengaruh yang kuat pada metode parenting seperti apa yang diterapkan oleh orang tua. Parenting adalah upaya pendidikan yang dilaksanakan oleh keluarga dengan memanfaatkan sumbersumber yang tersedia dalam keluarga dan lingkungan yang berbentuk kegiatan belajar secara mandiri.

Oleh karena itu, melalui program parenting sebagai wadah komunikasi antar orang tua, disamping untuk memberikan sosialisasi terhadap program-program yang diselenggarakan oleh lembaga pendidikan, secara umum tujuan program parenting adalah mengajak para orang tua untuk bersama-sama memberikan yang terbaik buat anak-anak mereka, sedangkan secara khusus tujuan pengembangan program parenting adalah meningkatkan pengetahuan dan keterampilan orang tua dalam melaksanakan perawatan, pengasuhan dan pendidikan anak di dalam keluarga sendiri dengan landasan dasardasar karakter yang baik.

Pengaruh storytelling terhadap kemampuan berkomunikasi bahasa Inggris. Dari hasil penelitian dan teori yang ada dapat disimpulkan bahwa storytelling telah memberikan pengaruh positif terhadap peningkatan kemampuan berkomunikasi bahasa Inggris siswa SMP Karya Bangsa Depok. Storytelling adalah sebuah teknik menyampaikan sebuah cerita dengan cara mendongeng. Teknik storytelling ini bermanfaat melatih kemampuan mendengar secara menyenangkan. Namun, tidak semua orang dapat melakukan teknik ini. Orang yang bermaksud menggunakan teknik storytelling harus memiliki kemampuan public speaking yang baik, memahami karakter pendengar, meniru suara-suara, pintar mengatur nada dan intonasi serta keterampilan memakai alat bantu. Dikatakan berhasil menggunakan teknik storytelling, jika pendengar mampu menangkap jalan cerita serta merasa terhibur. Selain itu, pesan moral dalam cerita juga diperoleh.

\section{SIMPULAN}

Berdasarkan hasil penelitian di lapangan dapat ditarik simpulan sebagai berikut: 1) terdapat pengaruh yang signifikan parenting dan storytelling secara bersama-sama terhadap kemampuan berkomunikasi bahasa Inggris Siswa SMP Swasta Depok. Hal ini dibuktikan dengan perolehan nilai Sig. 0,000 $<0,05$ dan $F_{h}=9,466$. Secara bersama-sama parenting dan storytelling memberikan kontribusi sebesar 28,7\% terhadap variabel kemampuan berkomunikasi bahasa Inggris; 2) terdapat pengaruh yang signifikan parenting terhadap kemampuan berkomunikasi bahasa Inggris Siswa SMP Swasta Depok. Hal ini dibuktikan dengan perolehan nilai Sig. $0,018<0,05$ dan $t_{h}=2,454$. Variabel parenting memberikan kontribusi sebesar $13,9 \%$ dalam meningkatkan kemampuan berkomunikasi bahasa Inggris; dan 3) terdapat pengaruh yang signifikan storytelling terhadap kemampuan berkomunikasi bahasa Inggris siswa SMP Swasta Depok. Hal ini dibuktikan dengan perolehan nilai Sig. $0,014<0,05$ dan $t_{h}=2,564$. Variabel storytelling memberikan kontribusi sebesar $14,84 \%$ dalam meningkatkan kemampuan berkomunikasi bahasa Inggris.

\section{DAFTAR PUSTAKA}

Arikunto, S. (2006). Prosedur Penelitian Suatu Pendekatan Praktik. Jakarta: PT Rineka Cipta.

Bailey, K. M., \& Nunan, D. (2005). Practical English Language Teaching Speaking. New York: McGraw-Hill.

Graddol, D. (2006). English Next. The British Council.

Sugiyono. (2008). Metode Penelitian Pendidikan: Pendekatan 
Kuantitatif, Kualitatif, dan $R \&$ $D$. Bandung: Alfabeta.
Tarigan, H. G. (2008). Berbicara Sebagai Suatu Keterampilan Berbahasa. Bandung: Angkasa. 